\title{
Effect of Tax Planning on Firm Value of Quoted Consumer Goods Manufacturing Firms in Nigeria
}

\author{
Umeh Valentine Chukwudi, Okegbe Theophius Okonkwo, Ezejiofor Raymond Asika* \\ Department of Accountancy, Faculty of Management Sciences, Nnamdi Azikiwe University, Awka, Nigeria \\ Email address: \\ felixerhirhie@yahoo.com (U. V. Chukwudi), to.okegbe@unizik.edu.ng (O. T. Okonkwo), thaddray4life@yahoo.com (E. R. Asika) \\ ${ }^{*}$ Corresponding author
}

\section{To cite this article:}

Umeh Valentine Chukwudi, Okegbe Theophius Okonkwo, Ezejiofor Raymond Asika. Effect of Tax Planning on Firm Value of Quoted Consumer Goods Manufacturing Firms in Nigeria. International Journal of Finance and Banking Research. Vol. 6, No. 1, 2020, pp. 1-10. doi: $10.11648 /$ j.ijfbr.20200601.11

Received: December 4, 2019; Accepted: January 6, 2020; Published: January 21, 2020

\begin{abstract}
This study determined the effect of tax planning on firm value in quoted consumer goods manufacturing firms in Nigeria. The specific objectives are to: Determine the effect of Effective Tax Rate (ETR) on firm value of Nigerian consumer goods manufacturing companies; Ascertain the effect of Book Tax Differences (BTDs) on the firm value of Nigerian consumer goods manufacturing companies. Ex-post facto research design was adopted for the study. A sample size 21 of firms was selected based on availability of the financial statement of the selected firms from the population of all the non-financial quoted on the Nigeria Stock Exchange. Data for the study will be obtained from annual published financial of the non-financial covering a period of ten years from 2009-2018. Ordinary lease square regression was used to test the three formulated hypotheses with the aid of E-View 9.0. This study found that Effective tax rate (ETR) to impact negatively on firm value, but this impact was statistically significant. However, the study found that, book tax difference (BTD); impact positively on firm value, but this impact was not statistically significant. The study therefore recommended among others that since the influence of effective tax rate is statistically significant and so, should be used as a determinant of firm value in Nigeria. Therefore on the basis of efficient use of tax rate to generate growth should be encouraged.
\end{abstract}

Keywords: Tax Planning, Firm Value, Tax Rate

\section{Introduction}

Tax is one of the major instruments of fiscal policy for regulating the economy of any nation. At various times, successive governments in Nigeria have employed the instrument of tax policy to encourage industrial and corporate growth in the private sector [1]. On the opposing side, taxation and tax policies in Nigeria do equally act as disincentive to manufacturing firms to create value for stakeholders and enhance the value of the firms. As noted by Gatsi, taxation, observably, plays a role in the misfortunes of the manufacturing sector because tax policies, apart from generating revenue for the state, serve several other purposes [2]. It can be used as an avenue to protect infant industries, create incentive for investors to invest in certain areas of the economy or to create disincentive for other activities Gatsi, Gadzo and Kportorgbi, [2]. For example, Dickson and Nwaobia noted that unfriendly tax policies is one of the many reasons for the growth of the underground economy, where law-abiding individuals and corporate citizens seek refuge from wrongs inflicted on them by government [3]. Corporate taxation is a veritable source of revenue to governments all over the world. In Sub-Sahara Africa, corporate bodies are liable to pay Company Income Tax on their assessable profit in line with the relevant tax laws in the various countries [4].

Overtime, disparities have been observed among companies in the payment of taxes. These disparities in tax payment suggest tax planning practices by corporate entities. Tax planning is any activity in compliance with the tax laws that can explicitly reduce a firm's tax burden, as demonstrated in its effective tax rate. It involves taking advantage of the flexibilities and loopholes existing in the tax laws to reduce tax liability [5]. It has the potential of reducing the tax liabilities of a firm, bringing about a higher after tax cash position [6]. Although there could be some legality in the practices, governments all over the world have 
remain committed to discouraging such practices because it is a shift of resources from the government to shareholders, thereby limiting government ability to carry out her constitutional functions.

The major challenge of corporate entities, and in particular manufacturing firms, come in a midst of high corporate tax rates and multiples of other taxes that lead to high effective tax rates far above the statutory company income tax rate. With the introduction of the Information Technology tax, there are about forty different taxes levied on companies and individuals (Taxes and Levies, Approved List for Collection Act 1998, [7]. Many of these taxes from the different levels of government overlap and are forcefully extracted from corporate organizations. The effect of these exactions of course is high cost structure for firms Nwaobia [1]. One will not fail to agree with Nnadi and Akpomithat, a tax policy defines the cost structure of firms as it is factored into pricing [8]. In addition, tax costs and eventual payout deplete the disposable income of individuals as well as the distributable profits of corporate organizations. These taxes in fact, do translate to a substantial cost to organizations and if not properly planned and managed can have adverse impact on the bottom line, cash flow and capacity to invest.

Studies on tax planning and firm performance cum value have yielded mixed results. Desai and Hines provide evidence on firm performance and tax planning behavior of firms [9]. Again, the study investigated the relationship between tightening of tax systems and market value of firms. This study of 850 listed US firms established that intensive tax planning is associated with higher firm performance. On the other hand, the study reported that tightening of the tax system is positively associated with higher market performance of firms.

Tax consequences are a motivating factor in many corporate decisions. Managerial actions designed solely to minimize corporate tax obligations are thought to be an increasingly important feature of corporate activity in recent time. Despite this obsession on the tax implication of firm decisions and transactions, not much has been done on the value relevance of corporate tax avoidance. In Sub-Sahara Africa, studies like; Onyeka and Nwankwo; Obinabo; Dalu, Maposa, Pabwaungana and Dalu; Kiabel and Nwokah, have shown a negative impact of tax avoidance on the economy as it limits government ability to carry out her constitutional functions, the value relevance of the practice leaves much to be desired [10-13]. The value relevance of corporate tax avoidance has not been given adequate attention in subSahara Africa where the capital markets are less efficient. There is therefore need to provide more empirical evidences on the consequences of managers action (Corporate Tax Avoidance) on shareholders wellbeing, as reflected in the firm value, using evidence from non-financial firms in Nigeria.

Despite of positive relationship, there are also some negative relationships between tax planning and firm value discovered in prior studies. Ftouhi, Ayed, and Zemzemtested whether firm tax planning could raise the firm value [14].
ETR proxy was used in their study. The study result found that there is significant negative and relationship between tax planning and firm value because of too much agency cost. This result is linear to the shareholder's worry regarding principle threat in tax. Furthermore, this study also finds that tax planning can drive towards permanent tax savings. On the other hand, Chen, Chen, Chen and Shevlin, found out in his research that tax planning can rises agency cost and decrease firm value [15]. They use both ETR and book tax difference as their tax planning proxies and it concluded that tax planning is not necessarily to increase firm va There is therefore need to verify the tax planning firm value nexus using firms quoted in the Nigerian stock exchange, and investigate possible medium for improving the impact for shareholders' benefit.

The study has a broad objective of investigating the effect of Tax Planning on firm value of consumer goods manufacturing companies in Nigeria. The specific objectives are to:

a. Determine the effect of Effective Tax Rate (ETR) on firm value of Nigerian consumer goods manufacturing companies.

b. Ascertain the effect of Book Tax Differences (BTDs) on the firm value of Nigerian consumer goods manufacturing companies.

\section{Review of Related Literature}

\subsection{Conceptual Framework}

\subsubsection{Tax Planning}

Tax is one of the major instruments of fiscal policy that is known to regulate the economy of any country in the world. As viewed from part of either theoretically or empirically, both provide famously known results which prove that tax is giving a big contribution to determine the capital structure of firms situated in all the nations. For instance, an instrument namely tax policy has been elected in order to stimulate the growth of private sector in the field of mainly industrial and corporate growth. Usually a firm will try to make tax planning optimization in order to enhance the income after tax. Tax planning consists of minimizing mainly the income tax in order to maximize the result after taxes [16]. A firm with good profit margin will increase the reputation of that particular the firm. Besides, other main purpose of tax planning is to create a firm's value and link this directly to quality of firm's managerial organization and planning. Managers will usually find a way to minimize their tax burden so that they would be able to gain tax benefits after tax returns or shareholder wealth.

Researchers over the years have adopted various measures of tax planning. One of such measure is the average Effective Tax Rate (ETR). The average effective tax rate as used by Phillips and Regois the ratio of total tax expenses to pre-tax income, though various methods of computation exist in the literature $[17,18]$. The average Effective Tax Rate does not accurately capture permanent difference between book and 
taxable income; hence it is often called a partial measure of non-conforming tax avoidance [19].

Aggressive Tax planning involves cost like reduced government revenue for important services like health care, hospitals, schools, security, aged care and support for people with disabilities, unfair competition for businesses that are complying with tax laws in the way the laws were intended to operate, transaction costs incurred in setting up the tax planning strategy, such as registration and legal fees to establish off-shore subsidiaries, the risk of detection if the activities are illegal, or in the 'grey' area. Empirical evidences reveal that the risk of detection increases as more firms engage in the same strategy, and also with the length of period a firm pursues the strategy, the increased ability of managers to use the opaqueness required to disguise some transactions in order to extract rents for themselves, the incentives required to encourage the tax manager or director to engage in these activities, as they face personal costs if detected [20, 21].

\subsubsection{Firm Value}

Firm value represents the assets owned by a company. It is crucial because it describes the prosperity of the business owners. The manager being the representative of the owners of the business is responsible for optimal maximization of the value of the firm which forms the fundamental objective of any organization. A high firm value indicates that the company is prosperous and hence the shareholders' wealth is maximized. The prosperity level of the shareholders and investors are reflected in the firm value. Firm value is an indicator used to assess the performance of a company. Investors also perceive the company through its firm value, and this is related to the stock price. According to Ftouhi, Ayed and Zemzem the high stock price will make a higher firm value [14]. Bhabra opines that firm value is the price paid by the wealthy buyer when a company is sold, and he also sees firm value as the objective value from the public and the orientation of company's survival [22]. From the preceding, it is clear that firm value is the investors' perception towards a company's success level, and this is usually associated with stock price. Firm value is typically indicated by price to book value (PBV). When the PBV is high, it, therefore, means that the principle of going concern is operational which translates into shareholders' wealth.

\subsubsection{Effective Tax Rate}

The effective tax rate is the average taxation rate for a corporation or individual. The effective tax rate for individuals is the average rate at which their earned income is taxed, and the effective tax rate for a corporation is the average rate at which its pre-tax profits are taxed [23] The effective tax rate is the average rate at which an individual is taxed on earned income, or the average rate at which a corporation is taxed on pre-tax profits.

This has been used in prior studies like Rego; Khaoula and Ayed; Seyram and Holyto measure a reflection of tax planning that decreases a firm's tax liability without necessarily decreasing its accounting income [18, 24, 25].
Corporate ETR basically assesses the tax performance of firms. Thus, it is the best measure to evaluate the actual corporate tax burdens. ETR is a commonly used measure of a firm's tax burden. ETR provides a basic summary statistic of tax performance which describes the amount of taxes paid by a company relative to its profit before tax. This measure reflects aggressive tax planning through permanent book tax differences, Khaoula, Amor \& Ayed [24]. The ETR is computed as tax paid/Profit before tax.

\subsubsection{Book Tax Differences}

Book-tax differences in general could be referenced as the differences between financial statement income and federal taxable income [26]. Book-tax differences arise because financial statement income is intended to assess the company's performance, while federal taxable income is intended to calculate the amount of tax to be paid. Book-tax differences are generally divided into two, namely the permanent differences and temporary differences. Permanent differences arise from income and expenses transactions that are recognized by accounting principles but not by tax rules, whereas temporary differences are caused by the difference in recognition time between the accounting principles and rules [27].

\subsection{Empirical Review}

Several previous studies have addressed the presence of book-tax differences; suggesting that the measure is able to reflect the earnings quality. Referring to Jackson, accounting rules provides more flexibility in presenting the financial statements relative to the tax laws [28]. The author suggests that the higher the difference between accounting income and taxable income, the lower the earnings quality. Jackson further emphasizes the importance of investigating the booktax differences and its ability to predict future earnings [28]. Book-tax differences are difference between amount of profit calculated based on accounting and profit calculated in accordance to tax regulations [29]. Each year the company's management prepares financial statements with two different objectives, namely to meet IFRS requirement and tax regulations.

Wilson, using a sample of 59 firms accused by the US government of engaging in tax shelter activity, examined the characteristics and financial reporting effect of tax shelter participation, on book-tax-differences of tax shelter participants and whether tax sheltering is associated with wealth creation for shareholders or with managerial opportunism. The result indicated that active tax shelter firms with strong corporate governance exhibit positive abnormal returns. This finding is consistent with tax sheltering being a tool for wealth creation in well-governed firms [30].

Chen, Chen, Cheng and Shevlin, study the relationship between tax aggressiveness and agency conflicts present in family firms and non-family firms [31]. The reason to deal with these two types of companies separately is that, according to the authors, the presence of members of the founding family in the ownership structure implies a greater 
potential for conflict between majority and minority shareholders and a lesser one between owners and managers in comparison to non-family firms. This difference can impact the costs and benefits of implementing more or less aggressive tax policies.

Towery, examined the effect of mandatory disclosures of tax aggressiveness to tax authorities on firms' reporting decisions [32]. Schedule UTP requires firms to disclose federal income tax positions to the Internal Revenue Service that have been classified as 'uncertain' for financial reporting purposes. In showing how Schedule UTP disclosure requirements affect private and public reporting decisions, the study provide insights into the usefulness of these disclosures. Using confidential tax return data and public financial statement data, the study find that after imposition of Schedule UTP reporting requirements, firms report lower financial reporting reserves for uncertain income tax positions, but do not claim fewer income tax benefits on their federal tax returns. These findings suggest some firms changed their financial reporting for uncertain tax positions to avoid Schedule UTP reporting requirements without changing the underlying positions.

Audrey, compared the tax aggressiveness of domestic and multinational firms, investigate the relationship between tax aggressiveness and multinational size, as measured by the number of foreign jurisdictions, and (3) assess the overall quality of FIN 48-related tax footnote disclosures provided by domestic and multinational firms, and consider their role in aggressive tax planning. The results suggest that multinationals are relatively more tax aggressive than domestic firms. Some evidence indicates that larger multinationals may be more tax aggressive than smaller multinationals. And lastly, the results supported a potential inverse relationship between disclosure quality and tax aggressiveness for multinational firms [33].

Abdul-Wahab and Holland, examined Tax Planning, Corporate Governance and Equity Value using a sample of UK quoted firms from 2005-2007 and data drawn from International Accounting Standard 12 Income Taxes (IASB, 2010) Effective Tax Rate (ETR) reconciliations. Using a data valuation regression model, the paper reports a negative relationship. Further, the relationship is robust to the inclusion of corporate governance measures which could be expected to moderate the potential implications of a tax related shareholder-manager information asymmetry. An innovation of this paper is in using the ETR reconciliations to examine sub-categories of tax planning activities. The findings have direct policy relevance for shareholders and tax administrations in monitoring and controlling firms' tax planning activities [34].

Danielle, Thomas and John, examined whether a firm's business strategy is associated with its level of tax avoidance. Next, they also investigate the association between the firm's business strategy and the extent to which it avoids tax in an aggressive manner. To identify firms' business strategies, they use a comprehensive measure of business strategy based on the theoretical framework of Miles and Snow (1978,
2003). They find that firms following Miles and Snows' Prospector (innovation and risk seeking) strategy avoid more taxes than both Defender firms (cost leadership and risk aversion) and firms following a more general (Analyzer) strategy [35].

Fuest, Spengel, Finke, Heckemeyer and Nuel, discussed the issue of profit shifting and "aggressive" tax planning by multinational firms. The paper makes two contributions. First it provides some background information to the debate by giving a brief overview of existing empirical studies on profit shifting and by describing arrangements for IP-based profit shifting which are used by the companies currently accused of avoiding taxes. The study shows that preventing this type of tax avoidance is, in principle, straightforward [36].

Clive, Petr and Jeffrey, examined the association between aggressive tax reporting and the incidence of alleged accounting fraud. Relying on several proxies for tax aggressiveness to triangulate our evidence, they generally find that tax aggressive U.S. public firms are less likely to commit accounting fraud. More specifically, four (two) of the five (three) proxies for firms' effective tax rates (book-tax differences) load positively (negatively) during the 19812001 period, implying that fraud firms are less tax aggressiveness [37].

Mosota, investigated the effect of tax avoidance on the financial performance of firms listed in the Nairobi Stock Exchange (NSE). Using a descriptive research design, data on size, institutional shareholding, government shareholding, age and intangible asset were collected for the sixty one (61) listed firms in the Nairobi Stock Exchange (NSE). His result reveals a significant positive impact of tax avoidance on the financial performance of the companies. Size, age and intangible assets were found to have a positive effect on financial performance, while leverage had a negative impact on the financial performance of sampled firms. $\mathrm{He}$ recommends that firms should be aggressive in tax avoidance in order to improve profitability [38].

Ftouhi, Ayed and Zemzem in their study 'Tax planning and firm value: evidence from European companies' using Regression analysis model (Generalized Least Squares (GLS) regression) adopt the Tobin's q model in examining the relationship between firms' value and tax planning with firm size, leverage, capital intensity, Dividend and Earnings management. As control variables, the study found that tax planning can be considered as steps taken by taxpayers so as to reduce tax liability in obtaining the tax saving benefits. The correlation analysis reveals that the correlation coefficients between various independent and control variables are significant [14].

Hoi-wu and Zhang, ascertained the impact corporate tax avoidance has on the cost of bank loans. Using a descriptive research design with cross sectional data, the Ordinary Least Square (OLS) regression and correlation analyses were used. Their findings reveal that banks perceive tax avoidance as an exposure to significant risk. Hence incurs more stringent non price loan terms, incurs a higher at issue bond spread and prefer bank loans to public bonds when financing with debt. 
Firms that avoid tax more, incurs higher spread when obtaining loans [39].

Chyz, Gaertner, Kausar and Watson, investigated whether firms with overconfident CEOs pursue more aggressive tax positions and yet assign high expectations of their final reliability, even if these positions were to be audited by a relevant taxing authority. In their empirical tests they first document positive associations between proxies for the aggressiveness of firms' tax positions and overconfidence. They then test for associations between overconfidence and the financial reporting of uncertain tax benefits under FIN 48. Prior tax aggressiveness research leads to the expectation of a similarly positive association with uncertain tax benefits. Instead, the study find that the same group of firms with overconfident CEOs report lower uncertain tax benefits in the financial statements [40].

Lee, Alfreda and Minton, critically reviewed the accounting literature of tax avoidance with an emphasis on theories of corporate tax avoidance as well as empirical proxies for tax avoidance. The agency theory should be one of the relevant analytical bases to improve the understanding of the interactions between managers and shareholders with respect to corporate tax avoidance strategies. A number of empirical proxies for corporate tax avoidance are computed using financial statement variables, but their relevance is limited for firms that engage in conforming tax avoidance that reduce both book and taxable income. Alternatively, tax shelters and uncertain tax benefits can be used as proxies for aggressive tax avoidance [41].

Akanksha, Jayant and Costanza studied on Debt, Bankruptcy Risk, and Corporate Tax Aggressiveness examine the effect of leverage and bankruptcy risk on corporate incentives to shelter income from taxes. Their empirical tests provide evidence that is consistent with these theoretical predictions. they show that leverage and bankruptcy risk relate negatively to sheltering and that the negative effects of bankruptcy risk and debt on sheltering are stronger for riskier firms; and weaker for larger, better governed, more profitable firms, and for firms that are in the "public eye" [42].

Nwaobia Kwarbai and Ogundajo, examined the effect of tax planning on firm value. The study covered 50 firm-year observations for the period 2010-2014. Data were sourced from the annual reports of the sampled companies and analyzed using descriptive and inferential statistics within a specified panel regression model. The joint effect of the considered tax planning proxies on the firm value was significant. While Effective tax rate (ETR), Dividend (DIV) and Firm age (FAG) are positively and significantly related to firm value. Firm size, leverage and tangibility exert negative effect on firm value. The study concluded that holistic approach to tax planning and optimal mix of tax planning strategies are important determinants of their effect on firm value [43].

Zhang, Cheong and Rajah, looks at the influence of corporate governance on the impact of tax avoidance on firm value and how this influence affects the valuation of shareholders. Taking the data of FTSE 350 firms on London Stock Exchange from 2008 to 2015 as the sample, the empirical results show evidence that the effect of tax avoidance is positive on firm value for firms with strong corporate governance and insignificant for firms with weak corporate governance. Among the corporate governance techniques, compensation incentives and board structure appear to have impacts on corporate tax avoidance and other proxies of corporate governance show no statistical significance on tax avoidance measures. Findings reveals that the relationship between corporate tax avoidance and firm value is found to be conditional to corporate governance at disaggregate level and the overall effect of corporate governance on the relationship is insignificant [44].

Sikes and Verrecchia, identify a pecuniary externality arising from corporate tax avoidance. The intuition is that firms share risk with the government via taxation. The lower the tax rate applied to a firm's earnings, the more risk is borne by its shareholders. As firms avoid more taxes in the aggregate, the variance of the market's after tax cash flow increases. Consequently, covariance risk, and thereby the cost of capital, increases for all firms. Consistent with their prediction, they find that firms' implied cost of capital is positively related to aggregate corporate tax avoidance. This result holds for tax-avoiding and non-tax avoiding firms, and is stronger for firms whose cash flow co-varies more with the market cash flow. U.S. multinationals' tax avoidance drives the pecuniary externality, consistent with only strategies that reduce a firm's marginal tax rate on income reducing risksharing [45].

Van Der Pilosexamined whether the proportion of the independent directors on the board have an influence on tax avoidance. With the fixed effect model and industry fixed effect model of the S\&P 500 firms over a nine-year period, he investigates the proposed research question. The results of the fixed effect model suggest that when there are more independent directors on the board, the level of tax avoidance will be lower. The proportion of independent board members has not a significant influence on tax avoidance. This might be due to the fact that S\&P 500 index firms have in general a high proportion of independent board members on the board. Another factor why the industry fixed effect model contradicts the prior literature is that the measure he used for tax avoidance, does not take the year-to-year volatility away [46].

Lanis, McClure and Zirnsak, analyzed the tax aggressiveness of major alcohol and bottling companies operating in Australia. Included in the analysis are both Australian and foreign owned businesses. In total 13 companies were analyzed and sample was broken up between profit or loss firms in consistency with the academic literature. Five companies were classified as loss, seven as profit and one as neither. Effective tax rates and book tax gaps were analyzed with respect to the sample. Using the Australian Taxation Office (ATO) tax data, six corporations paid tax at, or near, the statutory rate of 30 per cent in the 
financial years 2013-2014 and 2014-2015, two paid at a rate lower than 20 per cent (Asahi Holdings and Lion), and the other five paid nothing. Taken together, the large alcohol companies in Australia are paying much less tax than would be expected if the 30 per cent corporate income tax rate applied. The analysis found that the wine industry made only small tax contributions to the Australian community over the two years [47].

Razali, Ghazali, Lunyai and Hwang, determined the impact of tax planning on firm value of firms listed in Bursa Malaysia. Tax planning proxies in this study are the Effective Tax Rate (ETR) and Book Tax Differences (BTDs). The 387 samples data were collected from the DataStream from period of 2014 to 2016. After controlling the firm size, leverage, asset tangibility, firm age and dividend, the regression results show that ETR has a significant and positive relationship with firm value while BTDs has insignificant negative relationship with firm value. Firm with less tax planning activities may signal investors that the firm is more transparent in publishing their financial information. Most of our control variables such as leverage, asset tangibility, firm age and dividend have negative relationship with firm value [48].

Ranatarisza, determined the significant influence of book tax differences on price book value, manufacturing companies listed in Indonesian Stock Exchange. The independent variables were book tax different which measured using temporary differences and book tax different measured by permanent differences. The dependent variable was price book value. The data analysis involved descriptive statistics, classical assumption test, multiple linear regression and hypothesis-testing using Statistical Package for Social Science 21.0. The findings were: temporary differences did not have significant influence towards price book value, meaning that increasing temporary differences would result in insignificant increase in price book value and was not the main determining factor of price book value; permanent differences had significant influence towards price book value, which mean increasing permanent differences would increase price book value and was the main determining factor in describing level of company's price book value; there was significant, positive and simultaneous influence between temporary differences and permanent differences as the indicator of book tax different towards price book value in the companies [49].

\section{Methodology}

\subsection{Research Design}

Ex-Post facto research design was adopted. This is appropriate because the study aims at measuring the relationship between one variable and another in which the variables are not manipulated. This involves use of financial accounts of organizations to generate the financial analysis that will determine the significant difference.

\subsection{Population of the Study}

The population of the study comprised quoted consumer goods manufacturing firms on the Nigerian Stock Exchange (NSE) as at end of 2018 financial year. The population included firms. This quoted consumer goods manufacturing firms are twenty one (21) (See appendix).

\subsection{Sample Size of the Study}

Since the population of the population is not large, the researcher used all the population size for the study.

\subsection{Method of Data Analyses}

Being a panel data study, the study involve a series of analyses like the descriptive statistics, Breusch-Godfrey Serial Correlation test, Multi-collinearity test, test for the fixed effect and the random effect as well as the Hausman specification test. However multiple regression analysis was used in testing the formulated hypotheses using E-View 9.0 statistical software.

Model Specification

In testing for the value relevance of corporate tax avoidance and in testing for the moderating effect of agency cost mitigating variables on the nexus, we adapt a firm-value model originally derived from Ohlson (1995) and have been widely used in value relevance studies including those that relates to tax avoidance as used by Abdul Wahab and Holland (2012). Their model centered on Tax Planning, is given as:

The study modifies the above model to reveal moderating effects of corporate governance on the impact of tax planning on firm value.

FMV $=\beta_{0}+\beta_{1}$ BVEit $+\beta_{2}$ CTAit $1+\beta_{3}$ COGit $+\beta_{4}$ PFTit + $\beta_{5}$ CAPINTit $+\beta_{6}$ LEVit $+\beta_{7}$ EXGit $+\beta_{8}$ CTA it- $1 *$ COGit + $\beta_{8}$ MVEit DIV + AGE + zit

The model was modifies thus:

$$
\begin{gathered}
\text { TOBINS Q }=\beta_{0}+\beta_{1} \mathrm{ETR}_{\mathrm{it}}+\mu_{\mathrm{it}}--\mathrm{Ho}_{1} \\
\text { TOBINS Q }_{\mathrm{it}}=\beta_{0}+\beta_{1} \mathrm{BTD}_{\mathrm{it}}+\mu_{\mathrm{it}}-\mathrm{Ho}_{2} \\
\text { TOBINS Q } \\
\text { TOt }=\beta_{0}+\beta_{1} \text { FRMSIZ }_{\mathrm{it}}+\mu_{\mathrm{it}}--\mathrm{Ho}_{3} \\
\text { TOBINS Q }_{\mathrm{it}}=\beta_{0}+\beta_{1} \mathrm{LEV}_{\mathrm{it}}+\mu_{\mathrm{it}}--\mathrm{Ho}_{4}
\end{gathered}
$$

Where:

TOBINS Q=proxied for Firm Value

ETR is Effective tax rate

BTD is Book-tax difference

Tobins Q

$\mathrm{E}$ is error term.

\section{Analysis of Data}

\subsection{Correlation Analysis}

In examining the association among the variables, we employed the Pearson correlation coefficient (correlation 
matrix).

Table 1. Correlation Analysis Matrix.

\begin{tabular}{llllll}
\hline & TOBINS & ETR & BTD & FRMSIZ & LEV \\
\hline TOBINS & 1 & -0.6066108723 & 0.71782813069 & 0.8347865266 & 0.2042862342 \\
ETR & -0.6066108723 & 1 & -0.09851691358 & -0.7135033989 & 0.4908615182 \\
BTD & 0.7178281306 & -0.0985169135 & 1 & 0.5574851190 & 0.3962695741 \\
FRMSIZ & 0.83478652665 & -0.7135033989 & 0.5574851190 & 1 & 0.0003392697 \\
LEV & 0.20428623420 & 0.490861518225 & 0.3962695741 & 0.00033926979 & 1 \\
\hline
\end{tabular}

Source: researcher's computation (2019).

The use of correlation matrix in most regression analysis is to check for multi-colinearity and to explore the association between each explanatory variable (ETR, BTD, FRMSIZ and LEV) and the dependent variable (Firm Value) proxy as TOBINS Q). Table 2 focused on the correlation between Firm Value measured as Tobins $\mathrm{Q}$ and the independent variables (ETR, BTD, FRMSIZ and LEV).

Finding from the correlation matrix table shows that all our independent variables, $\quad(\mathrm{ETR}=0.61 ; \quad \mathrm{BTD}=0.72$; FRMSIZ $=0.83$ and $\mathrm{LEV}=0.20$ ) were observed to be positively associated with Firm Value. In checking for multicolinearity, we noticed that no two explanatory variables were perfectly correlated. This means that there is no problem of multi-colinearity between the explanatory variables. Multi-colinearity may result to wrong signs or implausible magnitudes in the estimated model coefficients, and the bias of the standard errors of the coefficients.

\subsection{Testing of Hypotheses Formulated}

In other to examine the impact relationships between the dependent variable TOBINS Q and the independent variables (ETR, BTD, FRMSIZ and LEV) and to also test our formulated hypotheses, we used a pooled multiple regression analysis since the data had both time series (2009-2018) and cross sectional properties (21 consumer goods quoted companies). The pooled interaction based multiple regression results are presented and discussed in Table 2 below.

Table 2. TOBINS Q Pooled Regression Results.

\begin{tabular}{|c|c|c|c|c|}
\hline \multicolumn{5}{|c|}{ Dependent Variable: TOBINS } \\
\hline \multicolumn{5}{|c|}{ Method: Least Squares } \\
\hline \multicolumn{5}{|c|}{ Date: $11 / 15 / 19$ Time: $08: 38$} \\
\hline \multicolumn{5}{|c|}{ Sample: 20092018} \\
\hline \multicolumn{5}{|c|}{ Included observations: 10} \\
\hline Variable & Coefficient & Std. Error & t-Statistic & Prob. \\
\hline $\mathrm{C}$ & 8.950282 & 0.890992 & 10.04530 & 0.0002 \\
\hline ETR & -0.700840 & 0.350205 & -2.001228 & 0.1018 \\
\hline BTD & 0.646265 & 0.313096 & 2.064113 & 0.0939 \\
\hline FRMSIZ & $1.32 \mathrm{E}-07$ & $3.18 \mathrm{E}-07$ & 0.416042 & 0.6946 \\
\hline LEV & 0.948093 & 0.606771 & 1.562523 & 0.1789 \\
\hline R-squared & 0.885524 & Mean dependent var & & 9.003000 \\
\hline Adjusted R-squared & 0.793944 & S. D. dependent var & & 0.982073 \\
\hline S. E. of regression & 0.445796 & Akaike info criterion & & 1.528944 \\
\hline Sum squared resid & 0.993672 & Schwarz criterion & & 1.680237 \\
\hline Log likelihood & -2.644721 & Hannan-Quinn criter. & & 1.362977 \\
\hline F-statistic & 9.669356 & Durbin-Watson stat & & 2.350885 \\
\hline Prob (F-statistic) & 0.014250 & & & \\
\hline
\end{tabular}

Source: Researcher's computation through E-view 9.0 statistical package.

In Table 2, R-squared and adjusted Squared values were (0.88) and (0.79) respectively. The indicates that all the independent variables jointly explain about $88 \%$ of the systematic variations in Firm Value (TOBINS Q) of our samples companies over the ten years periods (2009-2018). The F-statistics (9.67) and its P-value (0.01) show that the firm value regression model is well specified.

Test of Autocorrelation: using Durbin-Waston (DW) statistics which we obtained from our regression result in table 2, it is observed that DW statistics is 1.86 and an Akika Info Criterion and Schwarz Criterion which are 1.52 and 1.68 respectively also further confirms that our model is well specified. In addition to the above, the specific findings from each explanatory variable are provided as follows:

\section{Hypothesis One}

$\mathrm{HO}_{1}$ : Effective Tax Rate (ETR) has no significant effect on firm value of Nigerian consumer goods manufacturing companies.

Effective Tax Rate (ETR), based on the t-value of -2.00 and $p$-value of 0.00 , was found to have a negative influence on our sampled quoted companies Firm Value and this influence is statistically significant as its p-value is less than 0.05 value. This result, therefore suggests that we should accept our alternative hypothesis one $\left(\mathrm{HO}_{1}\right)$ which states that Effective Tax Rate (ETR) has significant effect on firm value of Nigerian consumer goods manufacturing companies. This means that on the basis of effective tax plan to generate firm value, firms with high tax planning value performs better. However, this result is statistically significant and therefore 
should be used for any policy consideration.

Hypothesis Two

$\mathrm{HO}_{2}$ : Book Tax Differences (BTDs) has no significant effect on firm value of Nigerian consumer goods manufacturing companies.

Book Tax Differences (BTDs) based on the t-value of 2.06 and $\mathrm{p}$-value of 0.09 was found to have a positive influence on our sampled quoted company's firm value and this influence was not statistically significant since its p-value was more than $5 \%$. This result therefore suggests that we should reject our alternative hypothesis two $\left(\mathrm{HO}_{2}\right)$ and uphold null hypothesis which states that Book Tax Differences (BTDs) has no significant effect on firm value of Nigerian consumer goods manufacturing companies. This means that effective tax rate impact positively on firm value. However, this influence is not statistically significant and so, should be ignored as a determinant of firm value.

\subsection{Discussion of Findings}

Effective tax rate (ETR) based on findings, was found to influence negative on our dependent variable, Firm Value, but this influence was statistically significant. This finding therefore supports the finding of Mohd Razali, Ghazali, Lunyai and Tan Hwang (2018) and negates our aprori expectation and the view of Antonio and Giliord (2014).

Book Tax Difference (BTD) based on findings, was found to also have a positive but not statistically in affecting our sampled companies value. This negates the findings of Mohd Razali, Ghazali, Lunyai and Tan Hwang (2018) and affirms the findings of Maria, Ina and Katharina (2016); Antônio and Tatiana (2015).

\section{Conclusion and Recommendations}

\subsection{Conclusions}

This study found that Effective tax rate (ETR) to impact negatively on firm value, but this impact was statistically significant. However, the study found that, book tax difference (BTD); leverage (LEV) and firm size (FRMSIZ) impact positively on firm value, but this impact was not statistically significant. In order to maximize the value of the firm, company's owners would like to minimize corporate tax payments net of the private costs of doing so; in other words they want the company to be optimally plan diligently. There has been little rigorous empirical analysis of the benefits and costs to corporations of being tax planning. In this study, we attempted to fill this void, at least in part, by investigating the market reaction to an initial press mention that a firm was involved in a corporate tax shelter.

\subsection{Recommendations}

Based on the findings of the study, the researcher recommends the followings:

a. Since the influence of effective tax rate is statistically significant and so, should be used as a determinant of firm value in Nigeria. Therefore on the basis of efficient use of tax rate to generate growth should be encouraged. b. Since the basis of effective use of book tax difference (BTD) to generate firm value of companies with high book value does not perform better as the analysis revealed should be discouraged, hence it cannot be used for any policy formulation.

\section{References}

[1] Nwaobia, A. N. (2013). Tax planning and corporate financial performance of listed manufacturing companies in Nigeria. Unpublished PhD Thesis, Department of Accounting, Babcock University, Nigeria.

[2] Gatsi, J. G., Gadzo, S. G. and Kportorgbi, H. K. (2013). The effect of corporate income tax on financial performance of listed manufacturing firms in Ghana. Research Journal of Finance andAccounting, 4 (15): 118-124.

[3] Dickson, T. U. \& Nwaobia, A. N. (2012). Impact of heavy taxation on Israel during Solomonic era: Implications for Nigerian tax system. Asian Economic and Financial Review, 2 (2): $337-346$.

[4] Offioug, U. B. (2013). Company Income Taxation in Nigeria. Lagos: CIBN press.

[5] Dyreng, S. D., Hanlon, M., \& Maydew, E. L. (2008). Longrun corporate tax avoidance. Accounting Review, 83 (1), 61-82.

[6] Chen, Z., Cheok, C. K. \& Raziah, R. (2016). Corporate tax avoidance and performance: evidence from China's listed companies Institutions and Economies 8 (3). 61-83.

[7] Bammeke, S. A. (2012). Tax implications of the ongoing banking sector reforms in Nigeria. Paper delivered at ICAN 2012 MCPE (Tax Practice Sector), Lagos, March 28-29.

[8] Nnadi, A., M., \& Akpomi, K. (2008). The effect of taxes on dividend policy of banks in Nigeria. International Research Journal of Finance and Economics, 19 (2): 1450-2887.

[9] Desai, M. A., \& Hines, J. R. Jr. (2002). Expectations and expatriations: Tracing the causes and conseq.

[10] Onyeka, V. N. \& Nwankwo, C. (2016). The effect of tax evasion and avoidance on Nigeria's economic growth. European Journal of Business and Management 8 (24).

[11] Obinabo, C. R. (2016). Effect of tax evasion and avoidance on Nigeria's economic growth. NG-Journal of Social Development 5 (4), 16-28.

[12] Dalu, T., Maposa, V. G., Pabwaungana, S. \& Dalu, T. (2012). The impact of tax evasion and avoidance on the economy: a case of Harare, Zimbabwe. African Journal of Economic and Sustainable Development, 1 (3), 284-497.

[13] Kiabel, B. D. \& Nwokah, N. G. (2009). Curbing tax evasion and avoidance in personal income tax administration: A study of the South-South States of Nigeria. European Journal of Economics, 15 (3). 16-61.

[14] Ftouhi, K., Ayed, A., \& Zemzem, A. (2014). Tax planning and firm value: evidence from European companies. International Journal Economics and Strategic Management of Business Process. 2nd International Conference on Business, Economics, Marketing and Management Research (BEMM'14). Vol. 4. 
[15] Chen, S., Chen, X., Chen, Q. \& Shevlin, T. (2013). Are family firms more tax aggressive than non-family firms? The Journal of Financial Economics, 95 (1), 41-61.

[16] Soufiene A., Khoula A., \& Mohamed A. O. (2016). Tax optimization and the firm's value: Evidence from the Tunisian context, Borsa Istanbul Review, 16 (3), 177-184.

[17] Phillips, J. (2003). Corporate tax-planning effectiveness: the role of compensation- based incentives. The Accounting Review 78 (1), 847-874.

[18] Rego, S. O. (2003). Tax-avoidance activities of U.S. multinational corporations. Contemporary Accounting Research 20 (4), 805-833.

[19] Badertscher, B., Katz, S., Rego, S., \& Wilson, R. (2015). Conforming tax avoidance and capital market pressure. Retrieved from: http://ssrn.com/abstract $=2619317$ on $20^{\text {th }}$ February, 2018.

[20] Chen, K. \& Chu, C. (2005). Internal control versus external manipulation: a model of corporate income tax evasion. RAND Journal of Economics, 36, (1), 151-164.

[21] Desai, M. A. \& Dharmapala, D. (2009b). Corporate tax avoidance and firm value, Review of Economics and Statistics 91 (3): 537-546.

[22] Bhabra, G. S. (2007). Insider ownership and firm value in New Zealand. Journal of Multinational Financial Management, $\quad 17 \quad$ (2), $142-154$. http://dx.doi.org/10.1016/j.mulfin.2006.08.001.

[23] Jon N. K. (2012). The Real Effects of Opacity: Evidence from Tax Avoidance. Current Version: November 2012.

[24] Khaoula P. A. \& Ayed, A. (2013). Tax planning and firm value: evidence from European companies. International journal of Economics and strategic management Business. 2nd International conference on Business, marketing and Management. Vol 4.

[25] Seyram K. \& Holy, K. K. (2014). Effect of tax planning on firms market performance: evidence from listed firms in Ghana. International Journal of Economics and Finance; Vol. 6, No. 3; 2014 ISSN 1916-971X E-ISSN 1916-9728 Published by Canadian Center of Science and Education.

[26] Moore, J. A. (2012). Empirical evidence on the impact of external monitoring on book-tax differences", Advances in Accounting, incorporating Advances in International Accounting, 28, 254-269.

[27] Huang, D. F., \& Wang, C. L. (2013). Book-tax differences and earnings quality for the banking industry: evidence from Taiwan", Pacific Accounting Review, 25 (2), 145-164.

[28] Jackson, M. (2009). Book-tax differences and earnings growth", Working Paper, University of Oregon.

[29] Hanlon, M. 2005. The persistence and pricing of earnings, accruals and cash flows when firms have large book tax differences. The Accounting Review 80 (1): 137-66.

[30] Wilson, R., (2009). An examination of corporate tax shelter participants. The Accounting Review 84 (3), 969-999.

[31] Chen, S., Chen, X., Cheng, Q., \& Shevlin, T. (2010). Are family firms more tax aggressive than non-family firms? Journal of Financial Economics, 95, 41-61. http://dx.doi.org/10.1016/j.jfineco.2009.02.003.
[32] Towery, E. M. (2012). How do disclosures of tax aggressiveness to tax authorities affect reporting decisions? Evidence from Schedule UTP. The University of Texas at Austin Red McCombs School of Business.

[33] Audrey E. M. (2012). Measuring tax aggressiveness after fin 48: the effect of multinational status, multinational size, and disclosures" (2012). Honors Scholar Theses. 217. http://digitalcommons.uconn.edu/srhonors_theses/217.

[34] Abdul-Wahab, N. S., \& Holland, K. (2012). Tax planning, corporate governance and equity value. The British Accounting Review, 44 (1), 1-14.

[35] Danielle, H., Thomas, C. O., \& John, D. P., (2013). The Influence of a Firm's Business Strategy on its Tax Aggressiveness. JEL classification: H25, L21, L22, M19, M41.

[36] Fuest, C.; Spengel, C.; Finke, K.; Heckemeyer, J. H.; Nuel P. A. (2013). Profit shifting and 'aggressive' tax planning by multinational firms: Issues and options for reform, ZEW Discussion Papers, No. 13-078.

[37] Clive, L., Petr, L. \& Jeffrey, P. (2013). Tax Aggressiveness and Accounting Fraud. Journal of Accounting Research Vol. 00 No. 0. DOI: 10.1111/joar.12002.

[38] Mosota, J. R. (2014). The effect of tax avoidance on the financial performance of listed companies at the Nairobi securities exchange. Unpublished Master Thesis, Department of Business Administration, School of Business, University of Nairobi.

[39] Hoi-wu, C. K \& Zhang, H (2013). Is Corporate Social Responsibility (CSR) Associated with Tax Avoidance? Evidence from Irresponsible CSR Activities. The Accounting Review. Nov. 2013. vol. 88, No 6, pp 2025-2059. https://doi.org/10.2308/50544.

[40] Chyz, J. A., Gaertner, F., Kausar, A. \& Watson, L (2014). Overconfidence and Aggressive Corporate Tax Policy. JEL classification: D80, M40, H25.

[41] Lee, B. B. Alfreda, D. \& Minton, S. (2015). Theories and Empirical Proxies for Corporate Tax Avoidance. Journal of Applied Business and Economics Vol. 17 (3).

[42] Akanksha, J., Jayant, R. K., \& Costanza M. (2016). Debt, Bankruptcy Risk, and Corporate Tax Aggressiveness. This version: December 24, 2016.

[43] Nwaobia A. N, Kwarbai, J. D., \& Ogundajo, G. O. (2016). Tax planning and firm value: empirical evidence from Nigerian Consumer Goods Industrial Sector. Research Journal of Finance and Accounting, 7 (2), 172-184.

[44] Zhang, C., Cheong, K. C., Rajah, R. (2016). Corporate Tax Avoidance and Performance: Evidence from China's Listed Companies. Institutions and Economies Vol. 8, No. 3, July 2016, pp. 61-83.

[45] Sikes, S. A. \& Verrecchia, R. E. (2016). Aggregate corporate tax avoidance and cost of capital. Paper presented at Indiana University Accounting Seminar, MIT Accounting Seminar, Ohio State University Accounting Seminar, Penn Tax Law and Policy Workshop, and the Tuck Finance, Economics and Accounting Seminar. 1-39.

[46] Van Der Pilos, N. (2017). Tax avoidance and corporate governance does the board of directors influence tax avoidance? Unpublished MSc thesis, department of: Accounting, Auditing \& Control, Erasmus School of Economics. 1-39. 
[47] Lanis, R., McClure R., \& Zirnsak, M. (2017). Tax aggressiveness of alcohol and bottling companies in Australia. Canberra: Foundation for Alcohol Research and Education. $1-32$.

[48] Razali, Ghazali, Lunyai and Hwang (2018). Tax planning and firm value: evidence from Malaysia. International Journal of
Academic Research in Business and Social Sciences 8 (11), EISSN: 2222-6990 (C) 2018 HRMARS.

[49] Ranatarisza, M. M. (2018). Whether book tax differences affect the price book value? RJOAS, 2 (74), DOI https://doi.org/10.18551/rjoas.2018-02.09. 